\title{
The Implementation of Buginese Leadership Trait
}

\author{
Syamsir Torang \\ University of Indonesia Timur, Makassar Indonesia \\ Doi:10.5296/jsr.v6i1.7331 \\ URL: http://dx.doi.org/10.5296/jsr.v6i1.7331
}

\begin{abstract}
Leadership trait constitutes significant factor in establishing success of a leader. Bugis ethnic group has several leadership trait they implement at work. They are getteng (firmness), lempu' (honesty), reso (dedication) and ammaccangeng (intelligence). The study aims to analyze the implementation of Buginese leadership trait through qualitative research methodology by case study approach. Research informants are several leaders from Bugis ethnic group who are working in public organization/bureaucracy, being a chief of politic party and informal leader. Informant as a Buginese leader is taken out by purpossive sampling technique, and informant as an informal leader is taken out by snowball sampling technique. Primary data is obtained by observation and structured interview, and the secondary one is obtained by documentary record. The data validity is assessed by credibility, transferability, reliability and confirmability test. The data is analyzed in four steps: data collection, data reduction, data presentation, and conclusion. The findings found that in a very pragmatic social, economic, politic atmospheres, then 1) the leadership trait of "getteng" (firmness) is not implemented in maximum, and so does 2) the implementation of "lempu" (honesty); however, it is recognizable that 3) the leadership trait of "reso" (dedication) and "ammacangeng" (intelligence) is implemented very well by Buginese leaders at work.
\end{abstract}

Keywords: Leadership Trait, Buginese, Indonesia

\section{Introduction}

Leadership trait of a leader is interestingly observed and analyzed since the leader has significant power over persons he led in an organization. Leader's power in the organization highly determines achievement of organization goals. Role, duty and function of a leader can make his subordinates motivated to work. Therefore, leadership character, style and trait of a leader also constitutes primary factor of success or failure in achieving organization vision.

Leader of organization is a part of socio-organization entity who plays functions in planning, organizing, actuating/directing and controlling. In addition to these functions, a leader also takes some duties like affecting, directing, regulating, coordinating all activities in the organization. It is to say that a leader in an organization is in role and process system and or in a relationship pattern that involves several persons to work together in performing role, duty, and function for organization goals. 
In performing the role, duty and function, a leader must be affected by the leadership trait he owns. According to Norman, R.F. (1970) trait approach is one of an effort to analyze leadership. Leadership trait is analyzed to find out or determine what makes someone become a great person or success. Besides, McBer (1991) emphasizes that leader is the primary source from which the leadership value will provide guidance to subordinate at work. Therefore, according to Schein, whatever the leader gives order, subordinates must obey and execute this order as they consider what is said and commanded by the leader is a good or right leadership value. Steadily, the value will be practiced and used as guidance by subordinate in work.

South Sulawesi is one of provinces in Indonesia made up by four (4) ethnic groups, they are: Bugis, Makassar, Mandar and Tana Toraja. Buginese people are a group of people at which most of them master in all dimensions of life in South Sulawesi, like economic, politic, social and cultural dimensions. Therefore, it is not surprising that, in general, many Buginese people become leader in public organization and politic party.

Aside from a fact as a single majority, Buginese people have possessed leadership values long time ago. The values has also used as a guidance by Buginese leader in having influence over his subordinate or junior (Kuntjaraningrat. 1981). Leadership trait attributed to the Buginese leader personality that up to now, the trait are used as the guidance. The trait are getteng (firmness and consistence), lempu' (integrity), reso (dedication), and ammacareng (intelligence) (Mattulada. 1976).

For leadership perspective in 20th century, Norman, R.F. (1970)) mentions 5 (five) primary leadership trait that are mandatory for a leader to be success: intelligence, self confidence, dedication, integrity and sociability.

Mar'at. 1986, asserts leadership trait is primary factor that defines his success in leading people. Leadership trait mentioned by Northouse and Yulk are same as what has been implemented by Buginese leaders previously. However, social, economic and political condition of Indonesian people tend to be more pragmatic as the consequence of weakening Buginese leadership trait. For that reason, the researcher is interested in observing and analyzing further to what extend Buginese leaders implement the trait that have been used as a guidance by previous Buginese leaders in performing their duties.

By taking formulation of research problem as described above, the study aims to analyze the implementation of Buginese leadership trait. Hopefully, the findings will become study material for knowledge development and references of future research, especially in leadership scope. Also, the findings can be used as information source for public organization leaders.

\section{Research Method}

\subsection{Type of Research and Research Approach}


Applied type of research in this research is qualitative. Bernardin et al., 1993 explains that qualitative research goes away from particular case existing in social situation. Then, to make an illustration about a more holistic leadership trait, the researcher take qualitative research out with an assumption that every context will relate to social situation (place, actor, and activity) to be analyzed critically (Kerlinger., 1986).

Research approach is case study. Creswell (Mar'at. 1986) affirms that case study is one of qualitative researches through deep exploration to keep the wholeness and integration of all research objects. The study is conducted in Makassar, South Sulawesi Province.

\subsection{Research Focus and Its Description}

Referring to the research problem and objective, the study focuses on leadership trait to which the dimensions are observed and analyzed; the dimensions are: Getteng (firmness and consistence), Lempu' (integrity), Reso (dedication), and Ammaccangeng (intelligence).

Description of this research focus is used as a reference or source in arranging research questions. In order to understand more about the research focus, operationally, every dimension of leadership trait and its indicator are described as follows:

a) Getteng (Buginese language) is translated "firm", a trait or character in firm and consistent ways in making decision or policy. If a decision or policy has been made, it must be addressed. The indicator is, if a leader says "yes", he will hold his view no matter till when.

b) Lетри' in Buginese language is translated integrity in English, a trait or character when a leader is honest and dependable. The indicator is, even it is hard, the leader is trustable and reliable because he never tells a lie or does corruption, collusion and nepotism.

c) Reso in Buginese language means dedication in English, a will and perseverance performed by a leader in handling duty/work no delay. The indicator is hard work and on-time job and assignment accomplishment.

d) Ammaccangeng, Buginese language, means intelligence, an ability or intellectual quotient (cognitif), emotional quotient (effective) and spiritual quotient owned by a leader. The indicators can be seen when a leader is intelligent and wise in making decision, he is loved by subordinates and society, and also religious.

Holistically, all dimensions in leadership trait are observed through social condition, including place where it takes place, actor, and activity of the leader.

\subsection{Data Source and Research Informant}

Research data is acquired from primary and secondary data. Primary data is collected through observation and interview in deep from informants. Secondary data is collected through documentation research concerning on research focus.

Research informants are Buginese ethnic chief, junior/subordinate and informal leader. Informants from leader group are taken out by purposive sampling. Informants from junior/subordinate and informal leader are taken out by snowball sampling. 


\subsection{Research Instrument}

The researcher himself will take a role as research instrument in addition to the three other instruments: interview, observation and documentary record. Questions are posed to informants in form of interview. Observation is carried out in social condition consisting of where it takes place (place), actor, and activity. Documentary records are all notes, information, instruction, law, government regulation, decision, organization structure, program, report and photos/film relevant to this research focus.

\subsection{Data Collection Technique and Data Validity}

Data collection technique applied in this study is structured interview, passive participant observation, and documentary research.

Bernardin et al., 1993 has a notion that data validity test in qualitative research can by conducted by these tests: a) internal validity (credibility), b) external validity (transferability), c) reliability (dependability), and d) objectivity (confirmability).

\subsection{Data Analysis Technique}

Data analysis technique for a qualitative research takes a guideline proposed by Miles and Huberman (Kerlinger., 1986), through 4 (four) steps: 1) data collection, 2) data reduction, 3) data presentation, and 4) conclusion.

\section{Findings And Discussion}

\subsection{The Leadership Trait of Getteng (firm and consistent)}

There are some leaders in South Sulawesi who are firm and consistent at leading or consistent at struggling for public interest in South Sulawesi, for some: Kahar Muzakkar (Islamic Fighter), a retired Major General M. Yusuf (a retired Commander of the Armed Forces of the Republic of Indonesia), H. M. Yusuf Kalla (vice-president of the Republic of Indonesia), and Ahmad Amiruddin (former Rector of Hasanuddin University and Governor of South Sulawesi).

Rao, T.V. (1992) affirms that not only leadership trait of "honesty" that determines a success of the leader in having influence over his subordinate, but it is also a leadership trait of "firmness".

The leadership trait of "firmness" stated by Yulk is not found anymore in most of Buginese leaders. Very pragmatic social, economic and political condition becomes primary cause that makes the researcher difficult to find Buginese leader (leader of public organization) who keeps the leadership trait of "getteng" (firm and consistent) alive at work. 


\section{MInstitute Macrothink $_{\text {Int }}$}

The fact above is confirmed by one of leaders (M) working in South Sulawesi Governor's office and he states that:

".....decision making in our organization is highly affected by social, economic and political interest of the top chief or external factor. For example, Position and Promotion Deliberating Agency (Badan Pertimbangan Jabatan dan Kepangkatan or BAPERJAKAT) has made policy by making appointment and order to any qualified person. However, the policy is suddenly canceled by the top chief or family of him without taking any consideration on the policy made by BAPERJAKAT. This fact conveys a meaning that we need not to make firmness and consistence a habit in making decision. We have frequently made decision/policy, but they are suddenly canceled due to pragmatic factor". Our firmness attitude in making decision is highly stipulated by situation and condition (situational)".

Pragmatic factor becomes the primary cause making Buginese leader of public organization hard to keep firmness and consistency alive in performing his role, duty and function.

\subsection{The Leadership Trait of Lempu' (integrity)}

In Buginese community, there are some advice conveyed by parents to their children. The word advises them to keep implementing honesty at work or someday in the future to be a "lempu" leader. The word as a "leadership value or trait" is made guidance all together by Buginese people at work or leadership.

Leadership trait of leaders in South Sulawesi, no matter where they are working in bureaucracy, government (public organization) or as the leader of political party, have not met lempu' (integrity) in performing the role, duty and function.

Today, the leadership trait of lempu' is nothing but a symbol. The leaders never told their subordinates or society what actually happens when they are forced to give gratification (bribe/corruption), or do collusion and nepotism. They do such just for holding and making their power eternal.

One of the leaders of public/government organization (M) tells:

"...if it is about political condition, we sometime tell a lie to people. So does what businessman treats us by asking gratification (bribe). It is hard for us to get around since we have to make a living or side income in addition to our salary. The money would be used to assist the governor/regent for the next regional election, or we have to help his family member who is going to take a part in mayoral/regential election. We have to provide mone, at least, IDR 300 million to help them. Besides, direct mayoral/regential election makes collusion spread rampantly. It is reasonable since the elected candidate of governor, regent or mayor would only promote those people or staffs who help him."

Similar with the problem faced by the leader of public organization, political party leader is also incapable of maintaining the leadership trait of Lempu' in his political movement. 
One of them (K) tells:

"...to get a change of being elected to be a member of House of Representatives of the Regency, a legislative candidate must provide money between IDR 300 million and IDR 1 billion. Such condition makes most of members of House of Representative of the Regency hunt for opportunity for side income to replace their capital money utilized in general election. The way how they earn side income is by proposing construction projects to the government (governor, regent or mayor). The projects will be handed over to friends of and family of him. By handling the projects, we will receive the profit as our side income".

What has been told by these two informants reveals a fact that the leadership trait of Lempu' (integrity) has not been a part of public activity performed by Buginese leader anymore. Accordingly, in general, public's trust in leaders is declining recently.

Norman, R.F. (1970) affirms that integrity means honesty and reliability of the leader who is obedient to the right principle and responsible for his act, and that is called integrity. A leader with integrity inspires the rise of self confidence in other persons because they are trustable to conduct what the leader commands. Integrity will make a leader can be trusted and is decent to hold the credence.

What is stated by Northouse above is no longer performed by most of Buginese leaders. This fact is said by a informal leader (A):

"...you will find difficulty to find a Buginese leader who keeps lempu' (integrity) alive nowadays at work. Perhaps, it is all about social, political and economic condition that they are not lempu' anymore. Worse when regential election is made directly when they have to spend so much fund to be elected. They do corruption to replace the money. No wonder why many leaders are being looked into by the law enforcer...so does the member of the House of Representative of the Regency who were elected but they bought the voice of the people. No need to be surprised when they do collusion and corruption with political executive to refund the fund ... that's why people have no longer trust to their leaders".

\subsection{The Leadership Trait of Reso (dedication)}

Buginese people has a motto in doing their activity, it says: "Reso pa Temmangingngi Naletei Pammase Dewata" it means with a hard working, you will have the mercy of God. Parents of former Buginese people had always advised their children, if you wish your dream comes true and get the mercy of God, be dedicated person and work hard (reso).

Dedication is eagerness to accomplish the work and it involves characteristic like initiative, steadiness, dominance and desire. A dedicated leader will force himself to be proactive, and is capable of standing firm when he faces an obstacle. A dedicated leader also shows domination over his subordinates in leading (Fahruddin. 1992) 
According to this 9-years research, the researcher found three regencies inhabited by Buginese people and led by a dedicated (reso) leader at work who also pursues his career in public organization (government) or bureaucracy. The three regencies with Buginese people are Bone, Soppeng and Wajo Regencies. One of indicators indicating their dedication in pursuing career is that, in general, the persons who occupy top leader in public organization (government) in South Sulawesi, are those from the three mentioned regencies.

One of leaders (success businessman and national leader) from Bugis ethnic groupBone-(AS) tells the researcher that:

"...I was poor, but I keep in my mind and implement what my parents had told me. I am obliged to be dedicated (reso) at work that God bless and grants what I've dreamed about. I hate a lazy youth ... to move forward and be success, you must be diligent".

What has been described by the researcher above does not imply that it is only leaders from the three regencies who are dedicated at work. In general, all leaders from any regencies (Bugis, Makassar, Tana Toraja and Mandar) in South Sulawesi are dedicated at work. However, it is only the leaders from three ethnic groups (Bone, Soppeng and Wajo) who dominantly are "reso (dedicated and hard worker)" at work.

\subsection{The Leadership Trait of Ammaccangeng (intelligence)}

In the history of the monarchy of South Sulawesi, there were 3 (three) groups of people who held an important position (leader) in monarchy or who served the monarch in running the monarchy. The three groups of people are: To Macca (the intelligence). To Warani (the hero), dan To Sugi (the rich). To Macca (the intelligence) is on top above three other groups. Intelligent leader means someone who has intelligence, emotional and spiritual (theology) quotients.

Intelligence (ammacareng) belongs to one of significant and must-have trait, especially for leaders of public organization or political party. Accordingly, one of recruitment requirements for a leader to be promoted in bureaucracy is the stages of his education. Almost all leaders (department heads) in bureaucracy or public organization have achieved M.A. level.

However, the findings reveal that intelligence (ammacangeng) or intellectual quotient owned by the leader of public organization (especially in departments) is still out of subordinate reach. It indicates that subordinate's intelligence is far different from the leader's. Consequently, the leader finds difficulty when he communicates with his subordinate.

Norman, R.F. (1970)) asserts that intellectual quotient of a leader shall not be far different from his subordinate. When it happens, it will be detrimental to the leader himself. A leader with a better intelligence than subordinate will find difficulties in communication when his ideas cannot be understood by the subordinate. 


\section{Macrothink}

Journal of Sociological Research

ISSN 1948-5468

2015, Vol. 6, No.1

The fact and notion of Northouse above is affirmed by one of public organization leaders $(\mathrm{N})$ who says:

"...sometimes, I have to make everything clear more than once when they do not understand my instruction or policy. For me, it happens when my subordinate's intelligence is just a standard high. So, I do suggest and approve their decision to take a higher degree ..."

\section{Conclusion}

Social, economic and political condition are so pragmatic preventing most of Buginese leaders (leaders of public organization) from developing the leadership trait of "getteng" in making decision. They are, in general, no longer "getteng" (firm) in making decision or policy. They are no longer "getteng" (consistent) in realizing the policy they have made.

The Buginese leaders nowadays, both who are in government (public organization/ bureaucracy) and political party leader, have not implemented the leadership trait of lempu' (integrity) maximum in taking the role, duty and function. They are aware of granting the gratification (bribe/corruption), doing collusion and giving the priority to their family and friend (nepotism). One of causal factors declining the leadership trait of "lempu" on Buginese leader is on socio-political factor (direct regential election).

The leadership trait of reso (dedication) performed by Buginese leaders, especially those from Bone, Soppeng and Wajo regencies, is exemplary trait. However, it does not imply that only three Buginese regencies who have the leadership trait of "reso" (dedication at work).

Almost all leaders of public organization/bureaucracy (department heads) have achieved M.A. level. It indicates that the intelligence (ammacangeng) or intellectual quotient of the public organization's leader (especially chief of departments) is good, but the subordinate has not achieved this level. Subordinate's intelligence is far different from the leader's. Consequently, the leader finds difficulty when he communicates with his subordinate.

\section{References}

Bernardin H. John and Joice F.A. Russel 1993 . Human Resource Management. Mc. Graw Hill.

Fahruddin. A.E. 1992 . Beberapa Nilai Sosial Budaya dalam Ungkapan Sastra Bugis . Ujungpandang: Finisi. Jurnal Pendidikan IKIP Ujung Pandang.

Kerlinger, F.N. 1986 . Fundation of Behavioral Research. Third Edition. Terjemahan Oleh Koesoeman. Yogyakarta: Gadjah Mada University.

Kuntjaraningrat. 1981 . Manusia dan Kebudayaan di Indonesia . Jakarta: Jambatan.

Norman, R.F. 1970 . Psychology in Industry . New Delhi: Oxford \& IBH Publising, Co. 
Mar'at. 1986 . Sikap Manusia Perubahan dan Pengukurannya. Jakarta: Ghalia Indonesia.

Mattulada. 1976 . Latoa: Suatu Lukisan Analisis Terhadap Antropologi Politik Orang Bugis (Disertasi). Jakarta: Universitas Indonesia.

McBer and Company dan ITB. 1990 . Achievement Motivation Traning (Tiga Macam Motif Sosial). Bandung: Pusat Peneltian Teknologi - ITB.

Rao, T.V. 1992 . Penilaian Prestasi Kerja Teori \& Praktek . Jakarta: Pustaka Binaman Pressindo Undang - Undang Dasar Republik Indonesia 1945. 